\title{
Invasive glossy buckthorn impedes growth of red oak and sugar maple under-planted in a mature hybrid poplar plantation
}

\author{
Caroline Hamelin ${ }^{1}$ Benoit Truax $^{2}$ - Daniel Gagnon ${ }^{1,2}$
}

Received: 7 January 2016/ Accepted: 13 August 2016/Published online: 22 August 2016

(C) The Author(s) 2016. This article is published with open access at Springerlink.com

\begin{abstract}
Native tree seedlings (nursery produced) were planted under control and herbicide treatments in the understory of a mature hybrid poplar plantation, naturally invaded by glossy buckthorn, a major invasive exotic shrub of Eastern North America. The objectives were to (1) test the negative effect of the invasive buckthorn on seedling growth, (2) determine if this effect differed for two tree species with different shade tolerances and edaphic requirements (sugar maple, red oak), and (3) determine if the type of canopy influenced this effect ( 5 clones). Confounding factors were reduced in this design (canopy composition and structure, age/size of seedlings), and several factors were controlled (transplantation date, deer exclusion). Several factors were measured (canopy openness, soil nutrients, canopy biomass, understory vegetation biomass, buckthorn density and biomass). After two growing seasons, seedlings of both species had reduced diameter and height increments under buckthorn. This difference was statistically significant for diameter increment. Canopy type did not have any effect on environmental variables or seedling growth. Buckthorn reduced light availability, but had no effect on soil moisture or soil nutrient availability. Consistent with sugar maple's ecological requirements, its diameter growth was explained (multiple regression) firstly by edaphic variables (positive effect: soil humidity and K), and secondly by buckthorn biomass (negative effect). Red oak growth was explained firstly by buckthorn biomass, and secondly by understory vegetation biomass, both negative effects. Seedlings of species with higher light requirements (red
\end{abstract}

Caroline Hamelin

hamelinc@uregina.ca

Benoit Truax

btruax@frfce.qc.ca

Daniel Gagnon

Daniel.Gagnon@uregina.ca

1 Department of Biology, University of Regina, 3737 Wascana Parkway, Regina, SK S4S 0A2, Canada

2 Fiducie de recherche sur la forêt des Cantons-de-l'Est/Eastern Townships Forest Research Trust, 1 rue Principale, Saint-Benoît-du-Lac, QC J0B 2M0, Canada 
oak) may have large growth reductions under buckthorn cover and have difficulty overtopping it. These results indicate that under-planting (plantations, forests) or afforestation should occur rapidly after buckthorn removal, otherwise this introduced invasive shrub may greatly reduce survival and growth of planted trees. Restoration of red oak to areas of former abundance will likely be more difficult because of the competition from glossy buckthorn.

Keywords Frangula alnus - Exotic shrub species · Introduced species · Acer saccharum . Quercus rubra . Early successional stands

\section{Introduction}

Forest managers and conservationists are very concerned by glossy buckthorn (Frangula alnus Mill.) (Fagan and Peart 2004; Webster et al. 2007), an exotic invasive shrub that is now dominant in several ecosystems in Eastern North America. Its spread is facilitated by openings in the forest canopy, even partial ones, resulting from cutting and thinning operations (Burnham and Lee 2009). It is a somewhat shade-tolerant species that out competes native species in the colonization of canopy gaps, where it tends to form a very dense mono-specific stand (Frappier et al. 2004; Nagel et al. 2008) limiting light availability for native tree seedlings. Additionally, when it becomes dominant, glossy buckthorn may possibly modify forest soil conditions through its uptake of resources (nutrients and water) and the addition of its litter to the forest floor (Fagan and Peart 2004). By limiting resources for tree seedlings, the regeneration of the canopy tree species can be delayed or arrested, reducing the diversity and productivity of the forest stand. Potential changes in forest species composition may also result in a lower value for the future forest (Fagan and Peart 2004).

A few authors have investigated the effect of buckthorn on forest understory tree seedlings. In forest environments and plantations, a higher basal area of glossy buckthorn has been associated with lower species richness and shifts in dominant vegetation towards shade-tolerant species (Frappier et al. 2003; Fagan and Peart 2004). Buckthorn presence or high basal area have also been associated with lower tree seedling survival, density and growth (Frappier et al. 2003; Fagan and Peart 2004). In an experimental field manipulation in New Hampshire, 2 years after removing buckthorn, Frappier et al. (2004) observed an increase in tree seedling density.

In contrast with these results, other authors did not observe any relationship when studying similar variables, although some of them studied the effect of buckthorn over a 15-year period (Houlahan and Findlay 2004; Mills et al. 2009; Owen Koning and Singleton 2013). This discrepancy perhaps indicates that the response to buckthorn invasion varies depending on the geographical location (Frappier et al. 2004; Ricciardi and Cohen 2007; Nagel et al. 2008) and on the type of ecosystem (Frappier et al. 2003).

Several authors have emphasized the importance of doing regional studies to evaluate the effects of invasive species (Frappier et al. 2004; Ricciardi and Cohen 2007; Nagel et al. 2008). Also, some types of forest have been shown to be more susceptible than others to invasion by buckthorn (Owen Koning and Singleton 2013) and the composition of a forest in terms of canopy trees may influence the effect of buckthorn on the forest understory. Research on the effects of buckthorn has been conducted mostly in the United States, in 
New England pine-mixed forests, and little information is available on buckthorn effects in other ecosystems. Southern Québec is a region of Canada that is most vulnerable to invasive species, because of its southern location (relatively warm climate and gateway for new invasive species) and the high fertility of its soils. In southern Québec, early successional, partially open hardwood forests and tree plantations appear to be particularly likely to be invaded by buckthorn. The afforestation of abandoned farmland (Cogliastro et al. 1990) and the restoration of valuable hardwood species to poorly regenerated second growth forests (Johnson 1975; Truax et al. 2000; Cogliastro and Paquette 2012; Dey et al. 2012) are becoming more widespread forest management practices. Whether or not the presence of glossy buckthorn has a negative effect on their success is a question that needs answering.

Studying invasive species is also important because there is evidence that rapidly spreading and abundant exotic species are not necessarily noxious for native ecosystems (Ricciardi and Cohen 2007). In some cases, an exotic species may be only taking advantage of the current conditions that are disadvantaging native plants, as opposed to driving changes in the ecosystem (Macdougall and Turkington 2005). Several authors have concluded that in many cases control actions were initiated against exotic species without solid evidence of their negative effect (Houlahan and Findlay 2004; Owen Koning and Singleton 2013; Lavoie et al. 2014).

To test the potentially negative effect of buckthorn on tree seedlings, we planted tree seedlings in the understory of a mature hybrid poplar plantation naturally invaded by buckthorn. Sugar maple (Acer saccharum Marsh.) and red oak (Quercus rubra L.) are the two native tree species we selected for this experiment. Sugar maple is one of the dominant hardwood species in the Northern Hardwoods forest region and red oak is one of its associated species (Godman 1992), and both species occur in the forests surrounding the study site. Both species are known for high quality timber production.

These two species differ in their tolerance to shade and in their edaphic requirements. Sugar maple is shade tolerant (Humbert et al. 2007) and has relatively high edaphic requirements (St. Clair and Lynch 2005), while red oak is a species of intermediate shade tolerance (Bazzaz and Carlson 1982; Gottschalk 1985; Humbert et al. 2007; Kolb et al. 1990; Phares 1971; Walters et al. 1993) with low to moderate edaphic requirements (Truax et al. 1994; Canham et al. 1996). The differences in shade tolerance and in edaphic requirements between the two species will allow us to assess if the effect of glossy buckthorn varies depending on the shade tolerance level and edaphic requirements of tree species seedlings.

The objectives of this study are: (1) to test the effect of glossy buckthorn on the growth of tree seedlings planted in the understory of a mature hybrid poplar plantation naturally invaded by buckthorn, (2) to determine if there are differences in this effect in two tree species that differ in their tolerance to shade and in their edaphic requirements (sugar maple and red oak), and (3) to determine if the type of hybrid poplar clone forming the canopy (5 clones tested) influences the effect of buckthorn on the growth of the tree seedlings.

\section{Materials and methods}

\section{Study site}

The study site is a 15-year old hybrid poplar plantation located at Sainte-Catherine-deHatley, in southeastern Québec (Lat. 45.27 N, Long. 72.05 W). Following site preparation (ploughing, disking and vegetation removal) in fall 1999, 2 m-long rooted hybrid poplar 
cuttings were planted in spring 2000. Glyphosate herbicide was applied over the entire plantation area in June 2000, and between the rows in June 2001 (Truax et al. 2012). Since the plantation's establishment, buckthorn has naturally invaded the plantation understory. The open abandoned field immediately adjacent to the plantation contains large clusters of buckthorn shrubs that were likely the seed source of individuals growing in the plantation.

The plantation covers approximately 0.5 ha and is entirely surrounded by a buffer row of hybrid poplars. It follows a randomized block design with 3 blocks, each including nine $12 \mathrm{~m} \times 12 \mathrm{~m}$ main plots, randomly attributed to 9 different hybrid poplar clones. Five clones, selected for their greatest differences in parentage, were used for this experiment. Each main plot has 12 planted hybrid poplars, for an initial density of 833 stems ha $^{-1}$ (Truax et al. 2012). Previous hybrid poplar biomass measurements required the harvesting of two trees per main plot (Fig. 1), which created light conditions comparable to that of woodlots where the forest has been thinned or where a small-scale disturbance has occurred.

The mature hybrid poplar plantation (15th growing season starting in spring 2014), offers a very uniform environment in terms of tree stem size and systematic horizontal spacing (structure). Structural uniformity is also due to the trees being hybrid poplar clones (genetically identical), which makes the canopy very homogenous. The understory environment (light, leaf litter, soil humidity, soil nutrients) of this plantation is comparable to that of natural early-successional or partially open forests common within the region.

Each main plot selected for the experiment ( 5 hybrid poplar clones $\times 3$ blocks $=15$ main plots) were split in two (1st split-plot level) and a herbicide treatment was randomly attributed

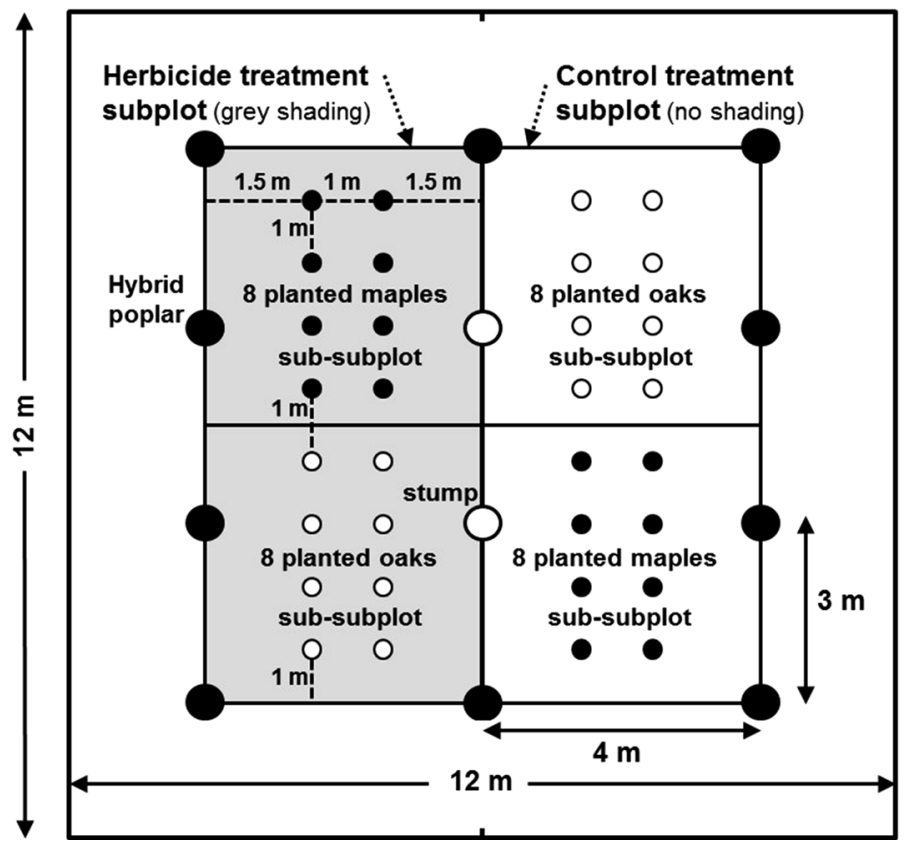

Fig. 1 Individual hybrid poplar clone plot $(12 \mathrm{~m} \times 12 \mathrm{~m}$, including 10 remaining hybrid poplars and 2 stumps) showing 2 treatment subplots (herbicide and control, randomly assigned left or right) and 4 planted tree sub-subplots (2 sugar maple subplots and 2 red oak subplots, randomly assigned location in each treatment) for a total of 4 experimental units per plot, and a total of 60 experimental units for the entire experimental design ( 4 exp. units/plot $\times 5$ hybrid poplar clones $\times 3$ blocks $=60$ ) 
to one half, while the other half remained untreated (control) for a total of 30 subplots (Fig. 1). In October 2013, double the minimal dose (7.52 $\mathrm{kg}$ a.i. ha ${ }^{-1}$ ) of glyphosate ("Round-up") was applied to the subplots identified for the herbicide treatment. In late April 2014, the remaining dead glossy buckthorn stems were cut and removed from subplots. No soil disturbances, weeding or additional herbicide treatments were done afterwards during the whole duration of the experiment. For the control treatment halves of the split design, the natural density of glossy buckthorn was preserved. A natural gradient in glossy buckthorn density from block 3 (glossy buckthorn at higher density, most likely first invaded through this block) to block 1 is associated to an opposite gradient of hybrid poplar biomass (resulting in greater canopy closure). In late April 2014, a 2.4 m-high (8 feet) plastic mesh fence was installed to protect the experimental design from deer browsing.

\section{Planted tree seedlings}

In conducting this experiment we used small gauge transplanted trees (nursery produced) to simulate large seedlings, which no previous field study of glossy buckthorn has done. Using transplants meant that all tree seedlings had the same age and cultivation history at the time of plantation, removing the heterogeneity in age and development that exists in natural forest understory seedlings. Moreover, using transplants more accurately represents an under-planting reality.

The tree seedlings were 1 year-old (1-0) container-grown seedlings. Average initial height was $62 \mathrm{~cm}$ for sugar maple and $35 \mathrm{~cm}$ for red oak. They were planted on May 6 and 7, 2014, in two rows of four trees, spaced $1 \mathrm{~m}$ between trees on the row, and $1 \mathrm{~m}$ between rows (Fig. 1). Eight tree seedlings of each species (2nd split-plot level) were planted in each sub-subplot $(2$ species $\times 2$ treatments $\times 5$ hybrid poplar clones $\times 3$ blocks $=60$ experimental units) for a total of 480 planted tree seedlings ( 240 per species) (Fig. 1). This experiment follows a split-split-plot design, as recommended by Petersen (1985), because the treatment (herbicide and control) and species (red oak or sugar maple) factors are added to an existing factorial design. The height and basal diameter of each planted tree seedling were measured initially on May 12 and 13, 2014 and at the end of each of the two first growing seasons (October 2, 2014 and September 22-23, 2015). The 8 tree seedling measurements of a sub-subplot were used to calculate a mean and are considered as a single "individual" to account for variability and mortality.

\section{Measurement of environmental and vegetation variables}

\section{Light availability}

Canopy openness, a proxy for light availability, was determined by the analysis of hemispherical photographs of the canopy, using the Gap Light Analyzer software v. 2.0. Two photographs were taken in each sub-subplot between July 7 and August 15, 2014: one at $1 \mathrm{~m}$ above the forest floor, below most of the buckthorn cover and above planted seedling height, and one at $3 \mathrm{~m}$, above most of the glossy buckthorn cover.

\section{Soil nutrients and humidity}

Plant Root Simulator ( $\mathrm{PRS}^{\mathrm{TM}}$-Probes) technology was used to determine soil nutrient availability, taking into account temporal variability (Western Ag Innovations Inc.). The PRS-Probes are pairs of ion-charged membranes (one for anions and one for cations) that 
are inserted in the soil at shallow depth for an extended period of time (40 days for this experiment) during which they exchange ions with those in the soil water. Three pairs of probes were inserted at $5 \mathrm{~cm}$ depth (from top of probe to soil surface) in each of the $60 \mathrm{sub}$ subplots from June 2 to July 11, 2014, corresponding to the peak of the growing season. Soil humidity was measured in each sub-subplot in July during a dry period (no rain $48 \mathrm{~h}$ prior to sampling) by conventional metal container samples for gravimetric measurements.

\section{Vegetation}

The diameter at breast height (DBH) of all hybrid poplars was measured on August 15, 2014, to calculate the poplar basal area, volume and biomass per main plot, using predictive equations (stem volume, aboveground woody biomass) developed for the 13-year old trees in the experimental hybrid poplar plantation network of Truax et al. (2014). In each sub-subplot, four $50 \mathrm{~cm} \times 50 \mathrm{~cm}$ microplots were used to estimate the biomass of the understory vegetation. All aboveground parts of plants within these microplots were harvested and dried in ovens to produce dry biomass data.

\section{Buckthorn}

To determine glossy buckthorn biomass in each sub-subplot, we used a predictive equation of aboveground biomass (Y), using basal diameter as the predictor variable (x) (allometric relationship). The predictive equation includes all aboveground biomass, including leaves, twigs and stems. Detailed methods to arrive at this predictive equation are presented in a previous publication (Hamelin et al. 2015). To calculate buckthorn biomass, we measured the basal diameter of all buckthorn stems taller than $50 \mathrm{~cm}$ in each sub-subplot. The diameter for each stem was transformed to biomass using the predictive equation and summed for each subplot. Buckthorn seedlings under $50 \mathrm{~cm}$ in height were counted in four $50 \mathrm{~cm} \times 50 \mathrm{~cm}$ microplots per sub-subplot to determine their density, and were then harvested to determine total buckthorn seedling dry biomass. Total buckthorn aboveground biomass in each sub-subplot was calculated by adding total seedling dry biomass (transformed to total sub-subplot area) and buckthorn (over $50 \mathrm{~cm}$ in height) aboveground dry biomass. To evaluate the efficacy of the herbicide treatment for controlling buckthorn over time, all buckthorn seedlings were counted after the second growing season (September 23 and 24,2015$)$ in one $1 \mathrm{~m} \times 1 \mathrm{~m}$ microplot established in each herbicide treatment subsubplot and their mean height was measured.

\section{Statistical analyses}

Tree seedling basal diameter and total height increments over two growing seasons (2014 and 2015) were used as response variables for the analyses of variance (ANOVA). The model for the ANOVA includes species (2), treatments (2), hybrid poplar clone types (5), blocks (3) and their interactions. Using this same model, we tested differences in environmental and vegetation variables between species, treatments, canopy hybrid poplar clones and between blocks. We used stepwise multiple regression procedures using the $\mathrm{R}$ program package (R Core Team 2014) to determine which environmental and vegetation variables explained the most variation in planted seedling growth of both tree species in all plots (response variables: increment in height and diameter over two growing seasons). Prior to the analyses, a correlation matrix was done to determine if some correlation 
Table 1 Results from ANOVAs ( $\mathrm{F}$ and $p$ values) on environmental and vegetation variables of three experimental blocks, five canopy hybrid poplar clone types, two treatments (control and herbicide) and two species (sugar maple and red oak) of planted tree seedlings in the understory of a mature hybrid poplar plantation

\begin{tabular}{|c|c|c|c|c|c|c|c|c|}
\hline \multirow[t]{2}{*}{ Variable } & \multicolumn{2}{|c|}{ Blocks } & \multicolumn{2}{|c|}{$\begin{array}{l}\text { Poplar clone } \\
\text { types }\end{array}$} & \multicolumn{2}{|c|}{ Treatments } & \multicolumn{2}{|c|}{ Species } \\
\hline & $F$ & $p$ value & $F$ & $p$ value & $F$ & $p$ value & $F$ & $p$ value \\
\hline \multicolumn{9}{|l|}{ Buckthorn } \\
\hline Stem density & 3.08 & 0.102 & 0.93 & 0.493 & 29.31 & $<0.001 * * *$ & 0.04 & 0.844 \\
\hline Seedling density & 7.42 & $0.015^{*}$ & 2.82 & 0.098 & 12.28 & $0.006^{* *}$ & 0.24 & 0.630 \\
\hline Total aboveground biomass & 7.58 & $0.014 *$ & 2.29 & 0.141 & 19.30 & $0.001 * * *$ & 0.48 & 0.496 \\
\hline \multicolumn{9}{|l|}{ Soil nutrients } \\
\hline $\mathrm{NO}_{3}$ & 3.00 & 0.107 & 0.99 & 0.465 & 0.76 & 0.404 & 1.32 & 0.264 \\
\hline $\mathrm{P}$ & 2.77 & 0.122 & 1.33 & 0.338 & 4.10 & 0.070 & 0.17 & 0.684 \\
\hline $\mathrm{K}$ & 1.28 & 0.329 & 2.11 & 0.171 & 1.59 & 0.236 & 0.85 & 0.368 \\
\hline $\mathrm{Ca}$ & 2.00 & 0.198 & 0.86 & 0.527 & 0.11 & 0.747 & 0.09 & 0.767 \\
\hline $\mathrm{Mg}$ & 0.51 & 0.619 & 0.65 & 0.643 & 2.00 & 0.188 & 0.00 & 1.000 \\
\hline Soil humidity & 5.68 & $0.029 *$ & 2.93 & 0.091 & 1.11 & 0.317 & 1.16 & 0.294 \\
\hline \multicolumn{9}{|l|}{ Canopy openness } \\
\hline $1 \mathrm{~m}$ & 0.11 & 0.897 & 0.26 & 0.896 & 17.99 & $0.002 * *$ & 0.04 & 0.844 \\
\hline $3 \mathrm{~m}$ & 1.76 & 0.233 & 0.38 & 0.817 & 10.79 & $0.008 * *$ & 0.01 & 0.914 \\
\hline $\begin{array}{l}\text { Understory vegetation biomass } \\
\text { (without buckthorn) }\end{array}$ & 1.71 & 0.241 & 0.45 & 0.770 & 29.16 & $<0.001 * * *$ & 0.51 & 0.483 \\
\hline \multicolumn{9}{|l|}{ Hybrid poplar } \\
\hline Basal area & 11.44 & $0.005 * *$ & 3.33 & 0.069 & & & & \\
\hline Volume & 12.97 & $0.003 * *$ & 2.95 & 0.090 & & & & \\
\hline Woody biomass & 13.06 & $0.003 * *$ & 5.45 & $0.020 *$ & & & & \\
\hline
\end{tabular}

* Significant at $0.01<p \leq 0.05$

** Significant at $0.001<p \leq 0.01$

$* * *$ Significant at $p \leq 0.001$

coefficients (r) between any two factors were over 0.5 (threshold for high colinearity). When this was the case, the factor less correlated with the response variable was removed. We executed "forward" selections, using the change in the model's $\mathrm{R}^{2}$ as the criterion to select which predictor variables to enter in the model. We evaluated the contribution of each predictor by the change in $\mathrm{R}^{2}$ and by the significance level of the ANOVA testing for the addition of the predictor.

\section{Results}

\section{Environmental and vegetation variations between clone type canopies and between treatments}

Table 1 shows the significance level ( $\mathrm{F}$ and $p$-values) of the differences for all measured variables. No significant differences were found for any of the soil nutrients between 
Table 2 Results from ANOVAs ( $p$ values) comparing environmental and vegetation variables between herbicide and control treatments in the understory of a mature hybrid poplar plantation

\begin{tabular}{|c|c|c|c|c|c|}
\hline Variable & Unit & Herbicide & Control & $\begin{array}{l}\text { Standard } \\
\text { error }\end{array}$ & $p$ value \\
\hline \multicolumn{6}{|l|}{ Buckthorn } \\
\hline Stem density & Stems $\mathrm{m}^{-2}$ & 0 & 5 & 1 & $<0.001 * * *$ \\
\hline Seedling density & Seedlings $\mathrm{m}^{-2}$ & 101 & 171 & 14 & $0.006^{* *}$ \\
\hline Total aboveground biomass & $\mathrm{g} \mathrm{m}^{-2}$ & 5 & 554 & 88 & $0.001 * * *$ \\
\hline Soil humidity & $\%$ & 20 & 19 & 0 & 0.317 \\
\hline \multicolumn{6}{|l|}{ Canopy openness } \\
\hline $1 \mathrm{~m}$ & $\%$ & 33 & 30 & 1 & $0.002 * *$ \\
\hline $3 \mathrm{~m}$ & $\%$ & 35 & 33 & 0 & $0.008 * *$ \\
\hline
\end{tabular}

(Significant Poplar clone type $\times$ treatment interaction for canopy openness at $3 \mathrm{~m}, p=0.017 *$ )

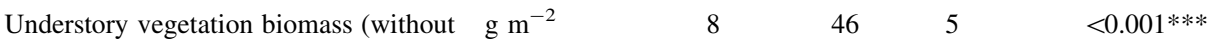
buckthorn)

* Significant at $0.01<p \leq 0.05$

** Significant at $0.001<p \leq 0.01$

$* * *$ Significant at $p \leq 0.001$

blocks, treatments or species. Hybrid poplar clone type canopy did not have any significant effect on any environmental or vegetation variable, or on tree seedling growth variables.

Detecting no differences in environmental variables among hybrid poplar clone type canopies is good evidence that it is highly unlikely that hybrid poplar clone type would have any effect on buckthorn. There also was no statistically significant hybrid poplar clone type effect on any buckthorn variables and on any tree seedling growth variables, nor was there a significant interaction between clone type and treatment. Our third hypothesis, about the potential of hybrid poplar clone canopy influencing buckthorn or its effect on tree seedlings, is therefore rejected. Boothroyd-Roberts et al. (2013) also did not observe any significant difference in environmental variables between 10 year-old hybrid poplar clone type canopies.

Table 2 shows the results of the ANOVAs comparing environmental and vegetation variables between treatments. Buckthorn was significantly more abundant in terms of stem density ( $>50 \mathrm{~cm}$ in height), seedling density $(<50 \mathrm{~cm}$ in height) and total biomass in control treatment plots than in herbicide plots. In control plots, mean buckthorn density was of 5 stems $\mathrm{m}^{-2}$ and of 171 seedlings $\mathrm{m}^{-2}$. In herbicide plots, buckthorns had been eliminated $\left(0\right.$ stems $\left.\mathrm{m}^{-2}\right)$, but seedling density (seedlings germinated in spring 2014) reached an average of 101 seedlings $\mathrm{m}^{-2}$ during the first growing season, and an average of 114 seedlings $\mathrm{m}^{-2}$ during the second growing season. Buckthorn seedlings in the herbicide treatment plots (germinated in spring 2014) had an average height of $25 \mathrm{~cm}$ after two growing seasons (September 2015). Buckthorns harvested for the development of the allometric relationship were up to 14 years old. This indicates that some of them invaded the plantation in 2001, 1 year after the site was prepared and the poplars were planted, and the same year that herbicide was applied between the poplar rows.

Understory vegetation biomass was also significantly higher in control plots than in herbicide plots. Nonetheless, in all control plots, where buckthorn and understory vegetation are both present, buckthorn biomass was much higher than that of the understory vegetation (mean per block). The biomass of the other understory vegetation (without 
Table 3 Results from ANOVAs ( $\mathrm{F}$ and $p$ values) of diameter and height growth increment over two growing seasons of red oak and sugar maple seedlings planted in herbicide and control treatments in the understory of a mature hybrid poplar plantation

\begin{tabular}{|c|c|c|c|c|c|c|}
\hline Variable & Red oak & $\begin{array}{l}\text { Sugar } \\
\text { maple }\end{array}$ & $\begin{array}{l}\text { Treatment } \\
\text { mean }\end{array}$ & $\begin{array}{l}\text { Treatment standard } \\
\text { error }\end{array}$ & $\mathrm{F}$ & $p$ value \\
\hline \multicolumn{7}{|c|}{ Basal diameter increment (mm) } \\
\hline Herbicide & 2.85 & 3.58 & 3.21 & 0.17 & 18.96 & $0.01 * *$ \\
\hline Control & 1.99 & 2.38 & 2.18 & & & \\
\hline Species mean & 2.42 & 2.98 & & & & \\
\hline $\begin{array}{l}\text { Species standard } \\
\text { error }\end{array}$ & 0.12 & & & & & \\
\hline $\mathrm{F}$ & 10.51 & & & & & \\
\hline$p$ value & $0.004 * *$ & & & & & \\
\hline \multicolumn{7}{|c|}{ Height increment $(\mathrm{cm})$} \\
\hline Herbicide & 27.86 & 12.16 & 20.01 & 0.93 & 2.94 & 0.12 \\
\hline Control & 25.19 & 10.35 & 17.77 & & & \\
\hline Species mean & 26.52 & 11.25 & & & & \\
\hline $\begin{array}{l}\text { Species standard } \\
\text { error }\end{array}$ & 1.30 & & & & & \\
\hline $\mathrm{F}$ & 68.98 & & & & & \\
\hline$p$ value & $<0.001 * * *$ & & & & & \\
\hline
\end{tabular}

** Significant at $0.001<p \leq 0.01$

$* * *$ Significant at $p \leq 0.001$

buckthorn) represented $31 \%$ of the total biomass of understory vegetation (understory vegetation + buckthorn) in block $1,12 \%$ in block 2 and $6 \%$ in block 3. Overall, buckthorn biomass was higher than that of the other understory vegetation by a ratio of 12 to 1 (554 vs. $46 \mathrm{~g} \mathrm{~m}^{-2}$ ).

At $1 \mathrm{~m}$ above ground level, under buckthorn cover and above planted seedling height, canopy openness was significantly lower in control plots than in herbicide plots. There was already a significant difference between treatments above most of the buckthorn cover (photographs at $3 \mathrm{~m}$ above ground level), but this difference is greater and more significant under the cover of buckthorn (photographs at $1 \mathrm{~m}$ above ground level). The significant interaction between poplar Clone type and Treatment for canopy openness at $3 \mathrm{~m}$ above ground (over most of buckthorn cover) appears to be a spurious effect, because treatment cannot have had any effect on the canopy above it, and it is unlikely that poplar clone type had an effect on treatment.

\section{Results of the tree seedlings experiment}

\section{Effect of buckthorn on tree seedling growth}

Over the two first growing seasons, mean diameter and mean height increments of the tree seedlings of both species were higher in the herbicide plots than in the control plots. These results support our first hypothesis about the negative effect of buckthorn on the growth of tree seedlings. Seedling diameter increment after two growing seasons was significantly higher in the herbicide treatment (Table 3). This difference increased from the first to the 
Table 4 Results of the stepwise regression analyses between environmental variables (predictor variables) and the total diameter increment over the two first growing seasons (response variable) for red oak and sugar maple seedlings for the control treatment plots in the understory of a mature hybrid poplar plantation

\begin{tabular}{|c|c|c|c|c|c|c|c|}
\hline Species & $\begin{array}{l}\text { Environmental } \\
\text { variables }\end{array}$ & $\begin{array}{l}\text { Parameter } \\
\text { estimate }\end{array}$ & $\begin{array}{l}\text { Parameter } \\
\text { significance } \\
(p \text { value })\end{array}$ & $\mathrm{R}^{2}$ & $\Delta \mathrm{R}^{2}$ & $\begin{array}{l}\text { Anova } \\
\text { between } \\
\text { models }\end{array}$ & $p$ value \\
\hline \multirow[t]{2}{*}{$\begin{array}{l}\text { Red } \\
\text { oak }\end{array}$} & $\begin{array}{l}\text { 1. Buckthorn } \\
\text { biomass }\end{array}$ & -0.001 & $0.001 * * *$ & 0.32 & 0.32 & $\begin{array}{l}\text { Model 1- } \\
\text { model } 0\end{array}$ & $0.001 * * *$ \\
\hline & $\begin{array}{l}\text { 2. Understory } \\
\text { vegetation } \\
\text { biomass }\end{array}$ & -0.009 & $0.01 * *$ & 0.46 & 0.14 & $\begin{array}{l}\text { Model 2- } \\
\text { model } 1\end{array}$ & $0.01 * *$ \\
\hline \multirow[t]{3}{*}{$\begin{array}{l}\text { Sugar } \\
\text { maple }\end{array}$} & 1. Soil humidity & 0.197 & $<0.001 * * *$ & 0.32 & 0.32 & $\begin{array}{l}\text { Model 1- } \\
\text { model } 0\end{array}$ & $0.001 * * *$ \\
\hline & $\begin{array}{l}\text { 2. Buckthorn } \\
\text { biomass }\end{array}$ & -0.001 & $0.006^{* *}$ & 0.49 & 0.16 & $\begin{array}{r}\text { Model 2- } \\
\text { model } 1\end{array}$ & $0.007 * *$ \\
\hline & 3. $\mathrm{K}$ & 0.006 & $0.02 *$ & 0.58 & 0.10 & $\begin{array}{r}\text { Model 3- } \\
\text { model } 2\end{array}$ & $0.02 *$ \\
\hline
\end{tabular}

\footnotetext{
* Significant at $0.01<p \leq 0.05$

** Significant at $0.001<p \leq 0.01$

*** Significant at $p \leq 0.001$
}

second growing season (data not shown). The difference between treatments in height increment over the two growing seasons was not significant $(p=0.12)$. Nonetheless, treatment means started to differentiate within a $3 \mathrm{~cm}$ range after two growing seasons, with the herbicide treatment showing a better mean height growth. The diameter difference may be small, but it is only one of two growth dimensions, which together produce a volume (3-dimensional). By using average height and basal diameter data, at planting and after 2 growing seasons, and making a basic volume calculation (using the cone volume formula) for both dates, we find that volume increment differences between treatments are $26 \%$ for red oak and $11 \%$ for sugar maple.

The effect of buckthorn did not differ significantly between species of tree seedlings (Treatment $\times$ Species interaction was not significant), therefore our second hypothesis is not supported.

\section{Environmental variables explaining tree seedling growth}

A stepwise multiple regression analysis indicates that the environmental and vegetation variables that explain a significant amount of variation in red oak basal diameter increment over two growing seasons are the amount of buckthorn biomass (negatively correlated), with a $\mathrm{R}^{2}$ of 0.32 , and the amount of understory vegetation biomass (negatively correlated), which adds 0.14 to the $\mathrm{R}^{2}$, for a total $\mathrm{R}^{2}$ of 0.46 for the explained variation of the response variable (Table 4). For sugar maple, the environmental and vegetation variables that explain a significant amount of the variation in its basal diameter increment are soil humidity (positively correlated), with a $\mathrm{R}^{2}$ of 0.32 , followed by the amount of buckthorn biomass (negatively correlated), with an additional contribution of 0.16 to the $\mathrm{R}^{2}$, and finally by soil $\mathrm{K}$ flux (positively correlated), with an additional contribution of 0.10 to the $\mathrm{R}^{2}$, for a total $\mathrm{R}^{2}$ of 0.58 for the explained variation of the response variable (Table 4 ). 
The results of multiple regression analysis for both species include buckthorn biomass, indicating that buckthorn presence influences the growth of both tree species. However, buckthorn biomass is included in the responses of the two species to a different degree, supporting our second hypothesis about the possibility of buckthorn having a different effect on seedling species differing in shade tolerance and edaphic requirements.

Similar stepwise multiple regression analyses were done on total height increment over two growing seasons for each species. No environmental or vegetation variables explained a significant amount of variation in this response variable for red oak, and only soil humidity (positively correlated) could explain a significant amount of variation in total height increment for sugar maple, with a $\mathrm{R}^{2}$ of 0.26 (not shown).

\section{Discussion}

Buckthorn did reduce light availability for seedlings growing under its cover, but it did not have an effect on soil water content or soil nutrient availability. No significant differences in edaphic conditions were observed between treatments, although the herbicide treatment resulted in the removal of an average $500 \mathrm{~g}$ of buckthorn dry biomass per $\mathrm{m}^{2}$. This is likely because the poplar overstory has a much greater effect on resources than the midstory buckthorn cover, as observed for other species by Brown et al. (2014). This result is also consistent with the description of glossy buckthorn as a species with low edaphic requirements, which does not require large amounts of water or soil nutrients, and which can therefore prosper in a very wide range of conditions and ecosystems (Mills et al. 2012). Light availability is the only environmental variable for which a significant difference was observed between control and herbicide treatments. A reduction in light availability by buckthorn had already been suggested before as buckthorn's main negative effect on native plant environment (Frappier et al. 2003). To our knowledge, it is the first time that it is experimentally measured and detected as statistically significant. This result suggests that seedlings of tree species with different light requirements could be affected to a different degree by buckthorn.

In our experiment, the ANOVA did not detect a significant Treatment $x$ Species interaction. However, the planted seedlings were still relatively small after two growing seasons (average height $73 \mathrm{~cm}$ for sugar maple and $62 \mathrm{~cm}$ for red oak), and this interaction may eventually appear as significant after several more years of growth. Nonetheless, some support for a different reaction to buckthorn by the seedlings of tree species with different edaphic and light requirements comes from the results of the multiple regression analyses. Different environmental and vegetation variables explain the variation in diameter growth of each of the two species tested, but both species have one variable in common, and that is the total aboveground biomass of buckthorn $\left(\mathrm{R}^{2}=0.32\right.$ for red oak; additional contribution to $\mathrm{R}^{2}$ of 0.16 for sugar maple). Aboveground biomass of buckthorn and other understory vegetation were the only two significant variables explaining variations in diameter growth for red oak. This result is consistent with the intermediate tolerance to shade of this species, which would make it more sensitive to shading by buckthorn. In contrast, two out of three significant variables explaining sugar maple diameter growth were edaphic variables (soil humidity and soil K). This is consistent with the high edaphic requirements of this species. These results suggest a differential effect of buckthorn on the diameter growth of seedlings of tree species based on their tolerance to shade, which is consistent with the observations of some authors of shifts in composition towards shade- 
tolerant species under buckthorn cover (Frappier et al. 2003; Fagan and Peart 2004). This species-specific effect on the seedlings could be compared to a "filter" through which not all tree species will equally grow and survive. George and Bazzaz (1999) described a "filter" effect produced by the fern understory stratum in New England deciduous forests, and they explained how it could lead to an altered canopy tree composition and to modifications in species distribution. Buckthorn could be creating a similar effect when it is abundant in the forest understory.

Buckthorn (total aboveground biomass) was the second most important variable explaining the variation in sugar maple diameter growth, which indicates that even species that are tolerant to shade can be affected by buckthorn. Our early observations that both a species tolerant to shade and a species of intermediate tolerance to shade are being affected in their growth by buckthorn, if maintained or amplified in the future, and if applicable to other species, could have serious consequences for the success of under-planting or the transition of seedlings to the canopy in natural forests, which could be reduced. Differences between treatments are likely to increase over the next years, as trees grow bigger and their light requirements increase to support growth.

The very high buckthorn seedling densities under the parent stems (171 seedlings $\mathrm{m}^{-2}$ on average in control plots) and in herbicide-treated plots (101 seedlings $\mathrm{m}^{-2}$ on average), and the rapid growth rate of these seedlings ( $25 \mathrm{~cm}$-high 2 years after germination), challenge the idea that native tree seedlings will be able to germinate, establish and be recruited in the stand if this competitive action of buckthorn is maintained. Planting tree seedlings to regenerate logged areas (clear cut or shelterwood cut) or understories of low density forests (ex. early successional intolerant hardwood stands) may be essential to ensure a well-stocked future stand. Follow-up measurements in our experimental design will provide information on whether a single herbicide treatment was enough to ensure the further development of the planted seedlings and their recruitment as saplings.

The results of this study on the effects of buckthorn on tree seedlings are likely to be generally applicable to early successional, partially open, hardwood forests [dominated mostly by intolerant hardwoods (poplars, birches, ashes, etc.)] that occur throughout southeastern Canada and the northeastern United States (Northern Hardwoods forest). This is because the understory environment of the 15-year old hybrid poplar plantation used for the experimental design has many environmental factors that are very similar to those of naturally regenerated forests of several decades in age (Boothroyd-Roberts et al. 2013). Indeed, Boothroyd-Roberts et al. (2013) found that 10-year old productive hybrid poplar plantations already had similar basal area, canopy closure and leaf litter accumulation, to that of nearby young second growth woodlots (ranging from 31 to 58 years in age).

\section{Conclusion}

Our short-term results on buckthorn seedling density and growth rate, and on the negative effect of buckthorn on native tree seedling growth provide support for the rapid reforestation or afforestation of sites that have been recently cleared and treated with herbicide, and more generally of sites that have a partially open canopy and moderately well to imperfectly drained soils. Relying on natural regeneration in these situations may be illadvised, especially in the highly fragmented landscapes typical of southeastern Canada, where remaining surrounding forested areas, upon which colonization success by native trees depends for seed sources, are often distant. Reforesting (after clear cutting) and 
afforesting (after agricultural abandonment) or under-planting (in appropriate early successional stands or mature poplar plantations) may be necessary in order to outpace buckthorn colonization.

Our conclusion is that shading by buckthorn is what produces the negative effect on tree seedling growth. Therefore, although shade-tolerant species, such as sugar maple, may be able to grow in the presence of buckthorn, albeit poorly, other species with higher light requirements, such as red oak or white ash, may have large growth reductions and have great difficulty passing through the buckthorn filter. Sugar maple is very rarely planted because it is abundant in naturally regenerated forests. Red oak, however, is a species of choice for under-planting and for plantations. Our results therefore have important implications for the restoration of red oak under partial tree cover if buckthorn has invaded the understory. Restoration of valuable hardwood species by under-planting in young lowdensity early successional forests or plantations on abandoned farmland are currently promoted by forest managers in Québec. However, under-planting may prove unsuccessful if no special management practices are developed to control this invasive introduced shrub.

Acknowledgments Research funding to the Eastern Townships Forest Research Trust by the Ministère des Forêts, de la Faune et des Parcs du Québec ("Chantier sur la forêt feuillue" Program) is gratefully acknowledged. We thank Amélie Lacroix-Dehours, Annie Richard, Olivier Dubuc, Marc-Antoine Pétrin, Daniel Hamelin and France Lambert for their assistance in the field. We also thank land owners Caroline Iannuzzi and Frédéric Nadeau for allowing this research project to occur on their property. We also wish to thank Harry Isbrucker for providing us with ample space for sample preparation and drying. Caroline Hamelin gratefully acknowledges graduate scholarships received from the Fonds de recherche du QuébecNature et technologies, from the Eastern Townships Forest Research Trust, and from the Faculty of Graduate Studies and Research of the University of Regina. We also thank two anonymous reviewers for providing constructive comments that helped to improve this manuscript.

\section{Compliance with ethical standards}

Conflict of interest The authors declare that they have no conflict of interest.

Open Access This article is distributed under the terms of the Creative Commons Attribution 4.0 International License (http://creativecommons.org/licenses/by/4.0/), which permits unrestricted use, distribution, and reproduction in any medium, provided you give appropriate credit to the original author(s) and the source, provide a link to the Creative Commons license, and indicate if changes were made.

\section{References}

Bazzaz FA, Carlson RW (1982) Photosynthetic acclimation to variability in the light environment of early and late successional plants. Oecologia 54:313-316

Boothroyd-Roberts K, Gagnon D, Truax B (2013) Can hybrid poplar plantations accelerate the restoration of forest understory attributes on abandoned fields? For Ecol Manag 287:77-89

Brown CE, Bailey BG, Saunders MR, Jacobs DF (2014) Effects of root competition on development of oak and chestnut regeneration following midstory removal. Forestry 87:562-570

Burnham KM, Lee TD (2009) Canopy gaps facilitate establishment, growth, and reproduction of invasive Frangula alnus in a Tsuga canadensis dominated forest. Biol Invasions 12:1509-1520. doi:10.1007/ s10530-009-9563-8

Canham CD, Berkowitz AR, Kelly VR et al (1996) Biomass allocation and multiple resource limitation in tree seedlings. Can J For Res 26:1521-1530

Cogliastro A, Paquette A (2012) Thinning effect on light regime and growth of underplanted red oak and black cherry in postagricultural forests of south-eastern Canada. New For 43:941-954. doi:10.1007/ s11056-012-9329-5

Cogliastro A, Gagnon D, Coderre D, Bhéreur P (1990) Response of seven hardwood tree species to herbicide, rototilling, and legume cover at two southern Quebec plantation sites. Can J For Res 20:1172-1182 
Dey DC, Gardiner ES, Schweitzer CJ et al (2012) Underplanting to sustain future stocking of oak (Quercus) in temperate deciduous forests. New For 43:955-978. doi:10.1007/s11056-012-9330-z

Fagan ME, Peart DR (2004) Impact of the invasive shrub glossy buckthorn (Rhamnus frangula L.) on juvenile recruitment by canopy trees. For Ecol Manag 194:95-107. doi:10.1016/j.foreco.2004.02.015

Frappier B, Eckert RT, Lee TD (2003) Potential impacts of the invasive exotic shrub Rhamnus frangula L. (glossy buckthorn) on forests of southern New Hampshire. Northeast Nat 10:277-296

Frappier B, Eckert RT, Lee TD (2004) Experimental removal of the non-indigenous shrub Rhamnus frangula (glossy buckthorn): effects on native herbs and woody seedlings. Northeast Nat 11:333-342

George LO, Bazzaz FA (1999) The fern understory as an ecological filter: emergence and establishment of canopy-tree seedlings. Ecology 80:833-845

Godman RM (1992) What are Northern hardwoods? In: Hutchinson JG (ed) Northern hardwoods notes. U.S. Department of Agriculture, Forest Service, North Central Forest Experiment Station, St. Paul, pp 1-3

Gottschalk KW (1985) Effects of shading on growth and development of northern red oak, black oak, blackcherry and red maple seedlings. I. Height, diameter, and root/shoot ratio. In: Dawson JO, Majerus KA (eds) Proceedings central hardwood forest conference V; April 15-17. SAF Publ. 85-05, Urbana. University of Illinois, Champaign-Urbana, pp 189-195

Hamelin C, Gagnon D, Truax B (2015) Aboveground biomass of glossy buckthorn is similar in open and understory environments but architectural strategy differs. Forests 6:1083-1093. doi:10.3390/f6041083

Houlahan JE, Findlay CS (2004) Effect of invasive plant species on temperate wetland plant diversity. Conserv Biol 18:1132-1138. doi:10.1111/j.1523-1739.2004.00391.x

Humbert L, Gagnon D, Kneeshaw D, Messier C (2007) A shade tolerance index for common understory species of northeastern North America. Ecol Indic 7:195-207. doi:10.1016/j.ecolind.2005.12.002

Johnson PS (1975) Eight-year performance of interplanted hardwoods in southern Wisconsin oak clearcuts. Research Paper NC-126. USDA Forest Service, North Central Forest Experiment Station, St. Paul, Minnesota

Kolb TE, Steiner KC, McCormick LH, Bowersox TW (1990) Growth response of northern red oak and yellow poplar seedlings to light, soil moisture and nutrients in relation to ecological strategy. For Ecol Manage 36:65-78

Lavoie C, Guay G, Joerin F (2014) Une liste de plantes vaculaires exotiques nuisibles du Québec: nouvelle approche pour la sélection des espèces et l'aide à la décision. Écoscience 21:133-156

Macdougall AS, Turkington R (2005) Are invasive species the drivers or passengers of change in degraded ecosystems? Ecology 86:42-55

Mills JE, Reinartz JA, Meyer GA, Young EB (2009) Exotic shrub invasion in an undisturbed wetland has little community-level effect over a 15-year period. Biol Invasions 11:1803-1820. doi:10.1007/s10530008-9359-2

Mills JE, Meyer GA, Reinartz JA, Young EB (2012) An exotic invasive shrub has greater recruitment than native shrub species within a large undisturbed wetland. Plant Ecol 213:1425-1436. doi:10.1007/ s11258-012-0101-X

Nagel LM, Corace RG III, Storer AJ (2008) An experimental approach to testing the efficacy of management treatments for glossy buckthorn at Seney National Wildlife Refuge, Upper Michigan. Ecol Restor 26(2):136-142

Owen Koning C, Singleton R (2013) Effects of moderate densities of glossy buckthorn on forested plant communities in southwest New Hampshire, USA. Nat Areas J 33(3):256-262

Petersen RG (1985) Design and analysis of experiments. Marcel Dekker Inc, New York

Phares RE (1971) Growth of red oak (Quercus rubra L.) seedlings in relation to light and nutrients. Ecology 52:669-672

R Core Team (2014) R: a language and environment for statistical computing. R Foundation for Statistical Computing, Vienna, Austria. http://www.R-project.org/. Accessed 15 Dec 2015

Ricciardi A, Cohen J (2007) The invasiveness of an introduced species does not predict its impact. Biol Invasions 9:309-315. doi:10.1007/s10530-006-9034-4

St. Clair SB, Lynch JP (2005) Differences in the success of sugar maple and red maple seedlings on acid soils are influenced by nutrient dynamics and light environment. Plant Cell Environ 28:874-885. doi:10.1111/j.1365-3040.2005.01337.x

Truax B, Gagnon D, Chevrier N (1994) Nitrate reductase activity in relation to growth and soil $\mathrm{N}$ forms in red oak and red ash planted in three different environments: forest, clear-cut and field. For Ecol Manag 64:71-82. doi:10.1016/0378-1127(94)90128-7

Truax B, Lambert F, Gagnon D (2000) Herbicide-free plantations of oaks and ashes along a gradient of open to forested mesic environments. For Ecol Manag 137:155-169. doi:10.1016/S0378-1127(99)00324-2 
Truax B, Gagnon D, Fortier J, Lambert F (2012) Yield in 8 year-old hybrid poplar plantations on abandoned farmland along climatic and soil fertility gradients. For Ecol Manag 267:228-239. doi:10.1016/j. foreco.2011.12.012

Truax B, Gagnon D, Fortier J, Lambert F (2014) Biomass and volume yield in mature hybrid poplar plantations on temperate abandoned farmland. Forests 5:3107-3130. doi:10.3390/f5123107

Walters MB, Kruger EL, Reich PB (1993) Growth, biomass distribution and $\mathrm{CO}_{2}$ exchange of northern hardwood seedlings in high and low light: relationships with successional status and shade tolerance. Oecologia 94:7-16

Webster CR, Jenkins MA, Jose S (2007) Invasion biology and control of invasive woody plants in Eastern forests. Native Plants 8(2):97-106 